\title{
Cellular Physiology during Logarithmic Growth of a Streptococcal L-Form
}

\author{
By C. PANOS \\ Research Laboratories, Department of Biochemistry, Albert Einstein Medical Centre, \\ Philadelphia, Pennsylvania and Department of Biological Chemistry, University \\ of Illinois College of Medicine, Chicago, Illinois, U.S.A.
}

(Received 16 November 1964)

\begin{abstract}
SUMMARY
Certain synthetic processes of a stable L-form and its parent streptococcus were compared to examine whether conversion was accompanied by significant alterations in the growth pattern. DNA and RNA were isolated from the streptococcus and its derived L-form, degraded, and molar base ratios measured and compared. Conversion to the L-form apparently did not result in a disturbance of synthetic processes related to DNA and RNA rates of syntheses and growth measured by extinction of cultures, colony count and dry weight increases. The stable L-form, although almost twice as slow growing, as compared with the streptococcus, retained the ability to function in an orderly manner and was capable of balanced growth. Conversion from streptococcus to $\mathrm{L}$-form did not result in an addition to the DNA base complement (5-methylcytosine, 5-hydroxymethylcytosine) nor in a quantitative alteration in the molar base ratio of either nucleic acid in the resulting $\mathbf{L}$-form. The disorganization in L-form division characteristic of L-form growth was not directly related to an obvious disturbance in any of the parameters examined.
\end{abstract}

\section{INTRODUCTION}

It has always been recognized that L-forms grow slower, display a smaller maximal growth response and result in yields of organisms (dry weight) appreciably lower than those of the parent bacterial form from which they are derived. Microscopically, the extreme diversity of sizes of the large bodies which comprise the structural components of the $\mathbf{L}$-form, and the complete lack of morphological similarity to the parent bacterial form, suggest that a permanent disorganization in cellular division has also occurred after conversion to the L-form. A stable L-form was found to possess altered physical, structural and metabolic properties following its derivation from a group A streptococcus (Panos, 1964a). However, biochemical information about the growth pattern of this L-form is lacking. It has been shown by Schaechter, Maaløe \& Kjeldgaard (1958) that Salmonella typhimurium can exist in one of a number of possible stable physiological states under conditions of balanced growth; similar information for the L-form considered here was lacking. The present work was undertaken to examine whether alterations in the synthetic processes (i.e. balanced growth) underlying the growth of the L-form had occurred after its conversion from the bacterial form. Part of these results were reported in preliminary form (Panos, 1964b). 


\section{METHODS}

The group A streptococeus and its derived stable $\mathbf{L}$-form were the same as that used previously (Panos, 1962). This non-pathogenic group A, type $12 \beta$-haemolytic streptococcus, lacking $M$ protein, has been successfully typed by its $T$ antigen (W. Hijmans, personal communication). The medium and growth conditions for each of these organisms were described by Panos \& Barkulis (1959). Identical results were obtained with the stable (i.e. not reverting to the bacterial form) $L$-form when it was grown in the presence and in the absence of penicillin. Five 1. medium were inoculated with 5 or $10 \%(\mathrm{v} / \mathrm{v})$ overnight inoculum of the streptococcus or its L-form, respectively, and $0.3 \mathrm{l}$. of culture removed at intervals for analyses. L colony counts were made as previously described (Panos, Barkulis \& Hayashi, 1960). Growth was followed by measuring the increase in extinction at $660 \mathrm{~m} \mu\left(E_{660}\right)$ in a Beckman DU spectrophotometer. Organisms were harvested and washed as described by Panos, Barkulis \& Hayashi (1959). For dry weight determinations, portions of washed suspensions of organisms were pipetted into tared beakers, dried $\left(90^{\circ}\right)$, placed over $\mathrm{P}_{2} \mathrm{O}_{5}$ and $\mathrm{NaOH}$ and weighed. Since the L-form organism is osmotically fragile, the $\mathrm{L}$-form content of $\mathrm{L}$-form $+\mathrm{NaCl}$ preparations was determined by weight difference and/or by determinations of nitrogen (Kjeldahl).

Before nucleic acid analyses, the organisms were extracted with $5 \%(w / v)$ trichloroacetic acid at $4^{\circ}$ until all material absorbing at $260 \mathrm{~m} \mu$ was removed. Extraction and colorimetric methods for these nucleic acid analyses were as given by Panos et al. (1959). Amounts of nucleic acids are expressed as \% of dry weight of total cellular material.

L-form organisms and streptococci were obtained from 18-hr cultures for ribonucleic acid (RNA) and deoxyribonucleic acid (DNA) base composition studies. The nucleic acids were extracted by several methods (Lee, Wahl \& Barbu, 1956; Sherratt \& Thomas, 1953; Sevag, Lackman \& Smolens, 1938), hydrolysed, and chromatographed and measured in the usual way (Lynn \& Smith, 1957). DNA was also isolated by the method of Marmur (1961). The streptococcus was disintegrated, either by ultrasonic treatment, grinding with alumina or shaking with glass beads in an International Centrifuge shaker head (Shockman, Kolb \& Toennies, 1957), for complete extraction of total nucleic acid content. The data presented are averages of at least two different experiments performed in duplicate.

\section{RESULTS}

Figure 1 illustrates the \% nucleic acid of the L-form organism and its parent streptococcus. The arrows indicate the prevailing concentrations during the respective logarithmic growth periods. The DNA content remained relatively constant for both organisms over the period examined. The RNA content reached a maximum of $20.6 \%$ for the streptococcus and only $13 \%$ for the L-form. The cellular dry-weight yields increased proportionally during logarithmic growth for both organisms. From extinction $E_{660}$ of $0 \cdot 050-0 \cdot 300$, the yields were 1.8-11.5 mg. and $2 \cdot 6-15 \cdot 4 \mathrm{mg} . / 100 \mathrm{ml}$. medium respectively for the $\mathrm{L}$-form and the streptococcus. The RNA/DNA ratio of the L-form changed as the cellular mass increased throughout most of logarithmic growth, as can be calculated 
from the data in Fig. 1 and the dry-weight yields cited. The maximal RNA/ DNA ratio reached within the L-form was about one-half that of the parent streptococcus. Since DNA/unit mass remained relatively constant in both organisms, the changes in these ratios were mostly the result of alterations in the RNA content/unit mass. In earlier work (Panos et al. 1959) done with cultures considerably beyond their logarithmic growth periods, RNA/DNA ratios were found to be lower, $4 \cdot 1: 1$ for the streptococcus and $4 \cdot 6: 1$ for the L-form. Although the

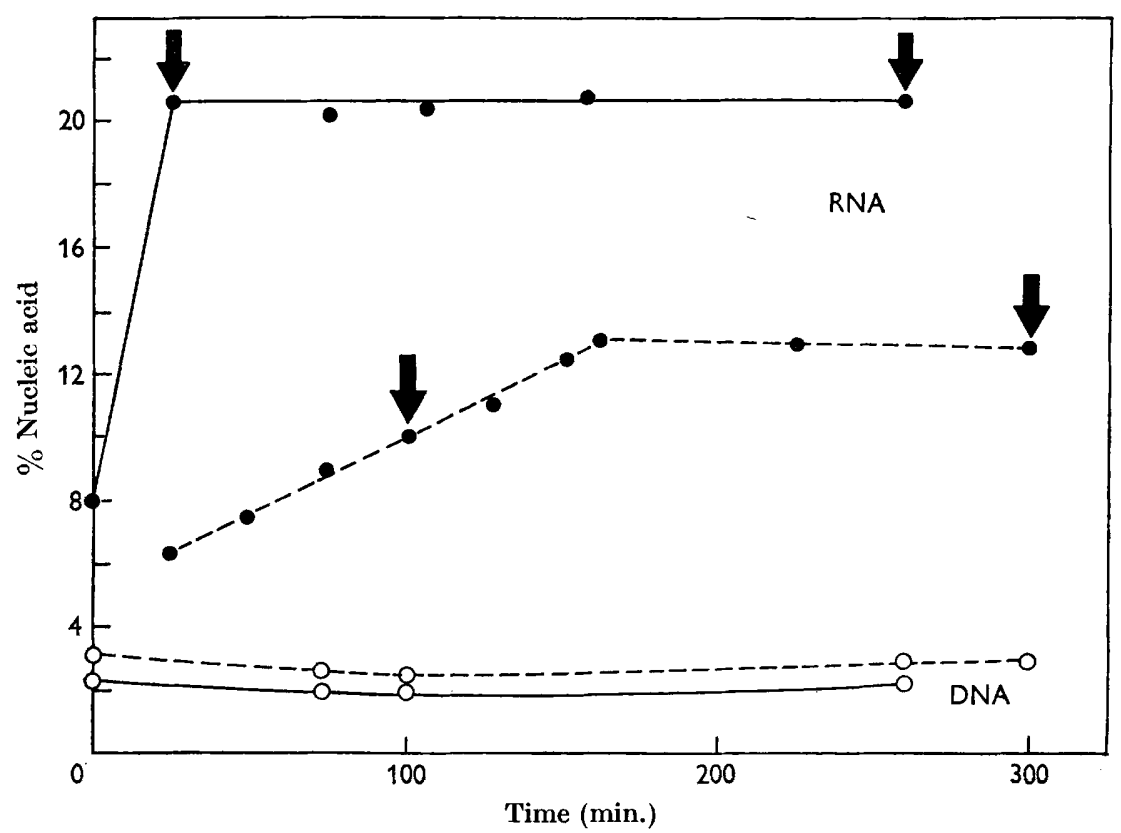

Fig. 1. RNA and DNA content of the derived L-forms (-- ) and the parent streptococcus (-). Arrows indicate concentrations during logarithmic growth phases. Cellular growth rate (doubling time): $\mathbf{5 0}$ and $\mathbf{8 0} \mathrm{min}$. for the streptococcus and $\mathbf{L}$-form, respectively.

DNA content of these older organisms agrees closely with those of logarithmically growing L-forms and streptococci, the RNA/DNA ratio was double $(10: 1)$ in the logarithmically growing streptococci. The logarithmically growing $\mathrm{L}$-forms showed only a slight increase in their RNA/DNA ratio over that of older organisms.

Figure 2 shows that increases in the rates of nucleic acid syntheses, extinction and colony counts paralleled each other during logarithmic growth of the L-form and of the parent streptococcus. The colony count data show that an increase in numbers of L-form bodies had occurred. A definition of 'growth' in terms of an increase in mass in place of an increase in numbers has already been used in protoplast investigations (Shockman \& Lampen, 1962). The rates of nucleic acid syntheses observed were much lower in the L-form. Over a comparable increase in extinction during the logarithmic growth period, the maximum amount of DNA synthesized by the L-form was about $66 \%$ of that of the streptococcus. Similarly, the maximum amount of RNA synthesized by the L-form was one-half that of the streptococcus. Although not illustrated, the stationary phase of growth was usually attained at an 
extinction $\left(E_{660}\right)$ between 0.8 and 0.9 for the streptococcus and 0.4 and 0.5 for its L-form.

RNA and DNA preparations from the streptococcus and L-form were isolated and degraded by various methods and the molar base ratios determined. Tables 1 and 2 show the analytical data for the nucleic acid bases obtained from both

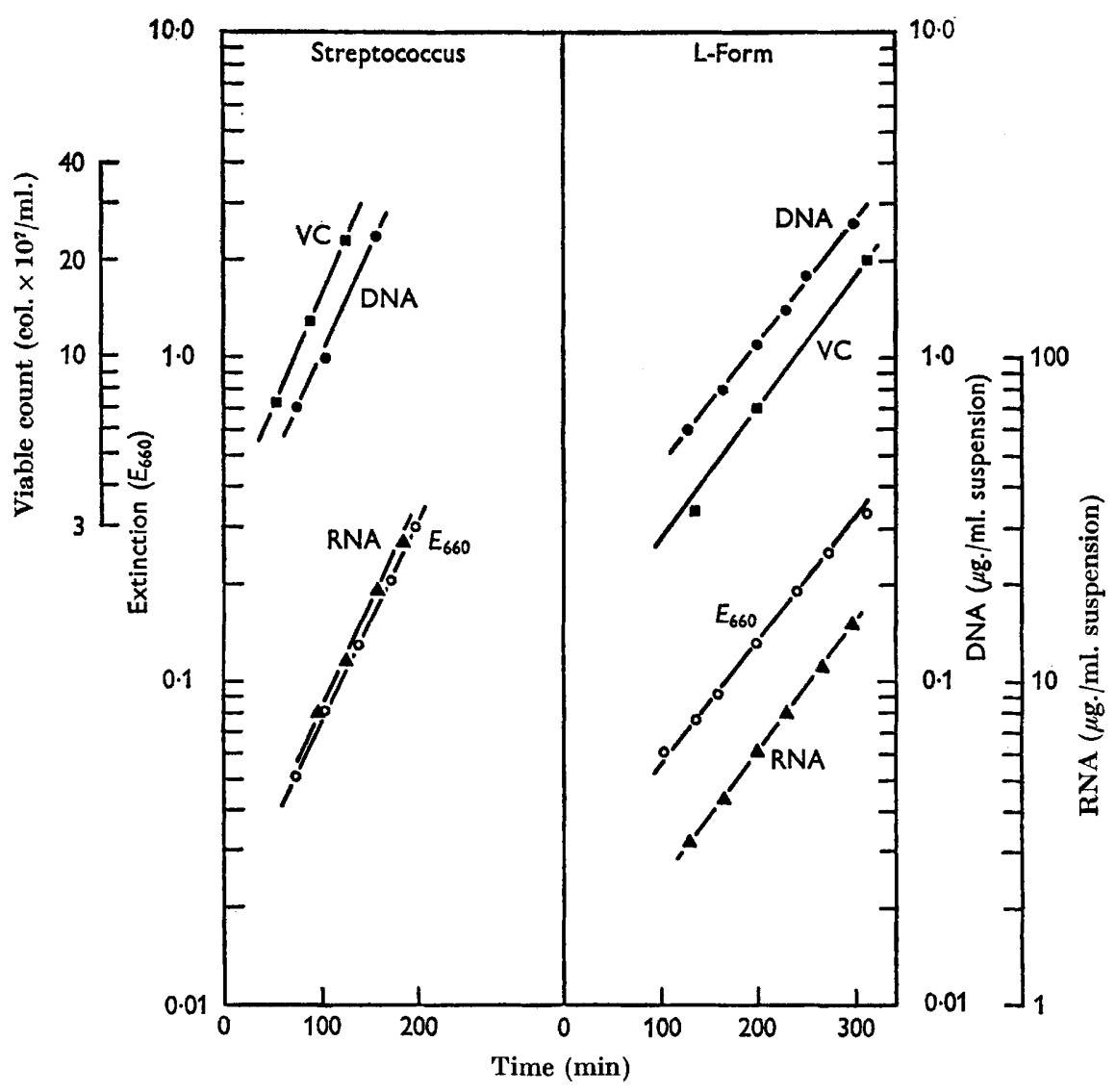

Fig. 2. Rates of nucleic acid syntheses, viable count and extinction increases during logarithmic growth of both organisms. $\mathrm{VC}=$ viable count.

Table 1. Analytical data (moles \%) of the deoxyribonucleic acid isolated from the streptococcus and its derived $L$-form

\begin{tabular}{|c|c|c|c|c|c|c|}
\hline Organism & $\underset{\text { (G) }}{\text { Guanine }}$ & $\begin{array}{l}\text { Adenine } \\
\text { (A) }\end{array}$ & $\begin{array}{l}\text { Cytosine } \\
\text { (C) }\end{array}$ & $\begin{array}{c}\text { Thymine } \\
\text { (T) }\end{array}$ & $\frac{\mathbf{A}+\mathbf{T}}{\mathbf{G}+\mathbf{C}}$ & $\mathbf{P u} / \mathbf{P y}$ \\
\hline Streptococcus & $\begin{array}{l}17 \cdot 1 \\
16.7\end{array}$ & $\begin{array}{l}32 \cdot 5 \\
32 \cdot 9\end{array}$ & $\begin{array}{l}17 \cdot 6 \\
17 \cdot 0\end{array}$ & $\begin{array}{r}\mathbf{3 2 \cdot 8} \\
33 \cdot 4\end{array}$ & $\begin{array}{l}1.88 \\
1.96\end{array}$ & $\begin{array}{l}0.98 \\
0.98\end{array}$ \\
\hline
\end{tabular}

organisms. No 5-methylcytosine or 5-hydroxymethylcytosine was observed in the DNA base complements from either organism. Failure to disrupt the streptococcus before these determinations by either of the methods mentioned (see Methods) 
prevented complete extraction of the nucleic acids and led to inconsistent results. The DNA base composition of the parent streptococcus agrees closely with values previously published for Streptococcus pyogenes.

The doubling times for each of the parameters studied were obtained from semilogarithmic plots of the respective data; these are tabulated in Table 3 . These doubling times were found to be greater for the L-form, and revealed a marked decrease in the rates of the cellular processes examined as compared with those of the streptococcus.

Table 2. Analytical data (moles \%) of the ribonucleic acid isolated from the streptococcus and its derived $L$-form

\begin{tabular}{|c|c|c|c|c|c|c|c|}
\hline Organism & $\begin{array}{c}\text { Guanine } \\
\text { (G) }\end{array}$ & $\begin{array}{l}\text { Adenine } \\
\text { (A) }\end{array}$ & $\begin{array}{l}\text { Cytosine } \\
\text { (C) }\end{array}$ & $\begin{array}{l}\text { Uracil } \\
\text { (U) }\end{array}$ & $\frac{G+U}{A+C}$ & $\frac{\mathbf{G}+\mathbf{C}}{\mathbf{A}+\mathbf{U}}$ & $\mathbf{P u} / \mathbf{P y}$ \\
\hline $\begin{array}{l}\text { Streptococcus } \\
\text { L-form }\end{array}$ & $\begin{array}{l}29 \cdot 6 \\
29 \cdot 7\end{array}$ & $\begin{array}{l}25 \cdot 6 \\
26 \cdot 1\end{array}$ & $\begin{array}{l}25 \cdot 0 \\
24 \cdot 0\end{array}$ & $\begin{array}{l}19 \cdot 9 \\
20 \cdot 2\end{array}$ & $\begin{array}{l}0.98 \\
0.99\end{array}$ & $\begin{array}{l}1.20 \\
1 \cdot 16\end{array}$ & $\begin{array}{l}1 \cdot 23 \\
1 \cdot 15\end{array}$ \\
\hline
\end{tabular}

Table 3. Doubling time (min.) of the parameters of the two forms studied

$\begin{array}{lcc} & \text { Streptococcus } & \text { L-form } \\ \boldsymbol{E}_{\text {680 }} & \mathbf{5 0} & \mathbf{8 0} \\ \text { RNA } & \mathbf{5 0} & \mathbf{7 6} \\ \text { DNA } & \mathbf{5 1} & \mathbf{8 0} \\ \text { Viable count } & \mathbf{4 5} & \mathbf{7 5} \\ \text { Dry weight } & \mathbf{5 0} & \mathbf{8 0}\end{array}$

\section{DISCUSSION}

Much information has accumulated about the biochemistry of bacterial L-forms. With regard to the stable streptococcal L-form used in the present work, it has been found that changes have occurred at the subcellular level (Panos, 1962; Edwards \& Panos, 1962) but that, for example, the vitamin requirements have remained unaffected following derivation from the parent streptococcus (Panos \& Hynes, 1964). There is little in the literature, however, about the growth physiology of coccal L-forms which lack the rigid bacterial cell wall. As is apparent from Fig. 1, the RNA content of this osmotically protected and structurally intact L-form does not approach that of the parent streptococcus. Since protein synthesis is related to RNA content, the proportional decrease in mass (i.e. protein synthesis) RNA content, as well as the decreased growth rate (Fig. 2), show that this relation has not been obviously disturbed by conversion of the streptococcus to an L-form. For Escherichia coli it has been shown that the soluble RNA/DNA ratio is a constant irrespective of the growth rate; the ribosomal RNA/DNA ratio, however, increases proportionally with the growth rate (Kjeldgaard \& Kurland, 1963). It is not known whether the decreased growth rate of the fragile streptococcal L-form represents an alteration in the ribosomal RNA content or is a manifestation of a less efficient ribosomal protein-synthesizing system. The RNA content during the stationary growth phase of each organism was not examined.

It has been shown that cellular DNA content has a tendency to remain nearly constant under different experimental conditions which affect bacterial 
growth rate. The derived L-form examined here displayed a decreased rate of DNA synthesis; the total cellular DNA content, as compared with the parent streptococcus, was nearly the same and was not affected by the inability of the L-form to synthesize the rigid bacterial cell wall.

The present results show some differences from those of Weibull \& Beckman (1960) for Proteus vulgaris and an L-form derived from it. The RNA content of both the Proteus and its L-form increased during early growth, followed by an abrupt and continuous decrease over the remainder of their growth cycles; also, there was no major difference between the growth rate and RNA content of the parent Proteus and its L-form. In contrast to their results, the RNA content of the streptococcus and its L-form studied here, while also increasing sharply, did not decrease but remained relatively constant once it had attained its maximum. Similarly, an appreciably slower growth rate (Table 3) and lower RNA content (Fig. 1) were observed for the L-form as compared with its parent streptococcus. The lower RNA content found in the streptococcal L-form is in agreement with a similar finding for a Proteus L-form by Kandler, Zehender \& Müller (1956) and Vendrely \& Tulasne (1953). Weibull \& Beckman (1960) suggested that the difference in the RNA content of their L-form from that found by Kandler et al. (1956) and Vendrely \& Tulasne (1953) might have been due to the latter authors having used L-form material ' . . . consisting to a large degree of vesicles apparently more or less empty'. In the present work very few such 'empty' vesicles were observed, yet the RNA content of the $\mathrm{L}$-form was lower than that of the parent streptococcus (Fig. 1).

The data presented here illustrate that in a nutritional medium similar to that of the parent streptococcus, conversion to the L-form apparently did not result in a disturbance of any of the synthetic processes underlying cellular perpetuation which were studied. The resulting L-form, although almost twice as slow in its rate of growth, continued to retain the ability to function in an orderly manner and was capable of balanced growth. These findings mimic the balanced growth results of Schaechter et al. (1958) with Salmonella typhimurium grown in a variety of media, from nutritionally complex to chemically defined. With the L-form used here, however, this decrease is associated with the permanent loss of ability to synthesize cell wall. Although our previous results suggest that conversion to the stable L-form results in a permanent disorganization of the cellular division process, these results could not be directly related to an obvious disturbance in any of the parameters examined; this suggests that the division process is probably distinct from that of balanced growth.

The DNA base findings given here represent the first such comparisons between a streptococcus and a derived stable L-form. No alterations were observed in an addition to the DNA base complement (5-methylcytosine, 5-hydroxymethylcytosine), nor in a quantitative alteration in the molar base ratios of DNA or RNA, on conversion to the L-form. The DNA from each source is of the 'AT-type', containing more adenine and thymine than guanine and cytosine; guanine was found to equal cytosine and adenine to equal thymine. In a similar study of a pleuropneumonia-like organism (PPLO), Lynn \& Smith (1957) observed that although the DNA base complement was of the 'AT-type', guanine was not equivalent to cytosine nor was adenine equal to thymine. The DNA purine/pyrimidine ( $\mathrm{Pu} / \mathrm{Py})$ 
ratio was $\mathbf{0 . 9 8}$ for the streptococcal L-form examined in the present work as compared with 0.86 for the PPLO.

The present RNA results are in accord with those of Mandel \& Sensenbrenner (1958) for Proteus vulgaris and an L-form derived from it. In both instances, no apparent differences were noted in the RNA base composition of these L-forms as compared with their parent bacteria. The pentose nucleic acid of the present streptococcal L-form is of the 'GC-type', containing more guanine + cytosine than adenine + uracil. The RNA Pu/Py ratio from the PPLO (also a 'GC-type') studied by Lynn \& Smith (1957) was 0.98 as compared with 1.15 for the present streptococcal L-form.

I am grateful to Miss M. J. Firszt for technical assistance, to Dr E. Barclay and Mr R. Rotundo of the Merck Sharp and Dohme Co., Inc. (West Point, Pa., U.S.A.) for a generous supply of horse serum, and to Dr G. D. Shockman (Microbiology Department, Temple University Medical School) for helpful criticisms during the preparation of this manuscript. The author is a Senior Career Development Awardee (U.S.P.H. 7-K3-GM-15, 531-02) and this work was supported by grants E-4543 and E-4495 from the National Institute of Allergy and Infectious Diseases, U.S. Public Health Service.

\section{REFERENCES}

Edwards, J. \& Panos, C. (1962). Streptococcal L-forms. V. Acid-soluble nucleotides of a group A streptococcus and derived L-form. J. Bact. 84, 1202.

KANDler, O., Zehender, C. \& Müller, J. (1956). Vergleichende Untersuchungen über Atmungsstoffwechsel von Proteus vulgaris, dessen stabiler L-Phase und den pleuropneumoniae-ähnlichen Organismen. Arch. Mikrobiol. 24, 219.

KJeldgaARD, N. O. \& Kurland, C. G. (1963). The distribution of soluble and ribosomal RNA as a function of growth rate. J. mol. Biol. 6, 341.

LeE, K. Y., Wahl, R.\& Barbu, E. (1956). Contenu en bases puriques et pyrimidiques des acides désoxyribonucléiques des bactéries. Ann. Inst. Pasteur, Paris, 91, 212.

Lynn, R. J. \& Sмrтн, P. F. (1957). Nucleic acid content of pleuropneumonialike organisms fròm human sources. J. Bact. 74, 811.

Mandel, P. \& Sensenbrenner, M. (1958). Étude comparée de l'acide ribonucléique du bacille Proteus et des formes L fixées qui en dérivent. Biochim. biophys. Acta, 29, 642.

Marmur, J. (1961). A procedure for the isolation of deoxyribonucleic acid from microorganisms. J. mol. Biol. 3, 208.

Panos, C. (1962). Streptococcal L-forms. IV. Comparison of the metabolic rates of a streptococcus and derived L-form. J. Bact. 84, 921.

Panos, C. (1964a). Streptococcal L-forms-A biochemical synopsis. Trans. N.Y. Acad. Sci. 26, 954.

Panos, C. (1964b). Cellular composition during growth of a streptococcus and derived L-form. Bact. Proc. p. 71.

Panos, C. \& Barkulis, S. S. (1959). Streptococcal L-forms. I. The effect of osmotic change on viability. $J$. Bact. $78,247$.

Panos, C., Barkulis, S. S. \& Hayashi, J. A. (1959). Streptococcal L-forms. II. Chemical composition. J. Bact. 78, 863.

Panos, C., Barkulis, S. S. \& Hayashi, J. A. (1960). Streptococcal L-forms. III. Effects of sonic treatment on viability. J. Bact. 80, 336.

Panos, C. \& Hynes, L. M. (1964). On growth and nutritional comparisons of a group A streptococcus before and after cell wall removal. Arch. Biochem. Biophys. 105, 326.

Schaechter, M., MaAløe, O.\& KJeldgaArd, N. O. (1958). Dependency on medium and temperature of cell size and chemical composition during balanced growth of Salmonella typhimurium. J. gen. Microbiol. 19, 592. 
Sevag, M. G., Lackman, D. B. \& Smolens, J. (1938). The isolation of the components of streptococcal nucleoproteins in serologically active form. J. biol. Chem. 124, 425.

Sherrate, H. S. A. \& Thomas, A. J. (1958). The nucleic acid fractions of a strain of Streptococcus faecalis. J. gen. Microbiol. 8, 217.

Shockman, G. D., Kols, J. J. \& Toennies, G. (1957). A high speed shaker for the disruption of cells at low temperature. Biochim. biophys. Acta, 24, 203.

Shockman, G. D. \& Lampen, J. O. (1962). Inhibition by antibiotics of the growth of bacterial and yeast protoplasts. J. Bact. 84, 508.

Vendrely, R. \& Tulasne, R. (1953). Chemical constitution of the $L$ forms of bacteria. Nature, Lond., 171, 262.

Weibule, C. \& BECKMAN, H. (1960). Growth of bacterial $\mathrm{L}$ forms and bacterial protoplasts. J. Bact. 79, 638. 